\title{
8 Hermeneutics and Psychoanalysis
}

\author{
Sebastian Gardner
}

\section{THE AMBIGUITY OF PSYCHOANALYSIS}

The relation of hermeneutics to psychoanalysis is close yet uneasy. Its crux lies in the distinctive and peculiar combination of conceptual commitments found in psychoanalytic explanation. Freud famously accords a presiding role to the practice of interpretation, whereby psychoanalysis is distinguished sharply from other schools of psychology, but he also denies that mental life is constituted throughout by meaning: interpretation may be the "royal road"1 leading to a new realm of psychological facts and therapeutic technique, but psychoanalysis does not confine itself to meanings and their relations.

This duality reflects another, closely associated ambiguity. The central explananda of psychoanalysis - dreams, symptoms, parapraxes, disturbances of affect, sexual perversions, and so on - present themselves as situated on the exact border between the personal and subpersonal. They belong on the one hand within the orbit of individual life, in a way that neural processes and the modules of cognitive science do not, yet they also signal points at which self-consciousness gives way to motivational forces which are no longer determinately personal but rather animal or even mechanical. Hence Freud's requirement that a special receptive stance, suspending the stamp of reflective personality, be adopted toward one's own mental life in order to release the initial data from which unconscious meanings can be extracted. ${ }^{2}$

Freud's inaugural hypothesis concerning the meaning of dreams postulates processes of "condensation" (Verdichtung) and "displacement" (Verschiebung). These bear loose comparison with

I am indebted to audiences at Bonn Universität and University College Dublin for comments on an earlier version of this chapter. 
metaphor and other poetic-linguistic operations, ${ }^{3}$ but they also, as Freud explains them, implicate concepts of mental force and mental location - the "economic" and "topographical" points of view. ${ }^{4}$ This conception of the dream-work, which transforms "latent" content into "manifest" content, implies that thought and meaning, in addition to playing their familiar rational roles, are also objects of quasimechanical manipulation within the psyche. Behind the dream-work lie other, more comprehensive principles of unconscious mental life, which Freud collectively gathers under the heading "primary process" - the pleasure principle, and the "special characteristics" intrinsic to the system Ucs., including timelessness and absence of contradiction $^{5}-$ and which again are essentially non-hermeneutical in character.

These assumptions are strictly necessary for Freud's dream interpretations: without the hypothesis of a mental apparatus which structures thought in accordance with principles that could not figure in self-conscious thinking, and shapes the mind's contents independently of any end that the agent could avow, the lateral connections Freud traces between words, ideas, memory-images and so on would simply not add up. Nor would it be possible to conceive dreams as meaningful wholes, that is, essential unities of latent and manifest content which can be translated into one another in the manner of texts, and regarded as expressions of emotion and desire. ${ }^{6}$

Individual psychopathology, and phenomena such as dreams, which ordinary psychological understanding is able to describe without pretending to explain, are what allows psychoanalysis to get its original explanatory purchase, but they do not of course exhaust its range. Having established what he takes to be the fundamental principles of mental functioning, Freud turns to the spheres of social and cultural life and makes deep incursions into the humanities and human sciences. A full account of Freud's interpretative ventures and the special problems which attend them (in particular with regard to artworks) is not possible here, but significant distinguishing features of the psychoanalytic treatment of socio-cultural phenomena include 
(1) its illumination of their deep roots in psychic life, which allow social and cultural practices to sustain and reproduce themselves in ways that public reason seems unable to account for, and (2) its power to rationalize not only normal but also pathological social forms. These features are chiefly responsible for the high interest which Freud holds for critical theory in the work of Fromm, Horkheimer, Adorno, Marcuse, and Honneth, who employ psychoanalysis to address the problems posed by ideological subjection, voluntary servitude, fascism, alienation, and so on.

Psychoanalysis thus in one respect offers itself to hermeneutical thought as an ally in the vindication and elaboration of concepts of meaning and understanding, which it shows to have greater scope than previously envisaged, contra reductive naturalistic forms of explanation in psychology and the human sciences; forms of psychology that by contrast merely analyse ordinary psychological understanding - as is the case when cognitive competences are decomposed into their functional elements - do not hold similar hermeneutical interest. Yet at the same time psychoanalysis poses a challenge by virtue of its apparent implication that meaning and understanding are precisely not self-sufficient in the way supposed by at least strong hermeneuticists such as Gadamer. Even when psychoanalytic explanation deals with the most quintessentially rational and meaning-constituted objects of enquiry - works of art, religious beliefs and practices, the normative social bond - it remains committed to showing that these derive ultimately from sources which, whatever they amount to exactly, cannot be regarded as securing their own intelligibility in the way that thinkers in the hermeneutical tradition, from Herder onwards, have standardly maintained with regard to Bildung, tradition, objective spirit, and suchlike. It is notable that Freud has no general theory of interpretation, either philosophical or psychological, and that it is not through reflection on the nature of understanding as such that he arrives at his conception of psychological interpretation. Freud's indifference to considerations central to philosophical hermeneutics is reflected 
in his attitude to language, to which he attaches importance only in so far as it provides (1) the mechanism and marker of consciousness, ${ }^{7}$ and, consequently, (2) the unique medium of therapeutic technique. Freud conceives therapy, furthermore, as directed to the bare hedonic end of reducing suffering: the idea that self-understanding, or interpretative self-constitution, is an end in itself which constitutes the final goal of therapy, is not found in Freud himself.

One conclusion which has been drawn is that psychoanalysis and hermeneutics are in fact irreconcilable. The real and abiding significance of psychoanalysis, it has been argued, lies in its demonstration of the explanatory superficiality of hermeneutical notions in contrast with robust, physically identified causes. ${ }^{8}$ Freud's avowed positivism gives some grounds for this, but he also disclaims any direct access to the organic substrate of mental activity: in The Interpretation of Dreams Freud makes clear that his explanatory goals presuppose the autonomy of the psychological, at least as a methodological principle. ${ }^{9}$ Proponents of natural-scientific readings of Freud, while acknowledging that the tendency of their approach is to reduce psychoanalysis to an anticipation of cognitive science and neuropsychology, have defended it nonetheless by arguing that hermeneutical construals fare worse in salvaging its truth-content. It is argued that, given the hermeneuticist's (alleged) dissociation of meaning from the controls of causal reality, it becomes impossible to say in what, other than subjective gratification, the correctness or validity of a psychoanalytic interpretation might consist. ${ }^{10}$ What may consequently be recommended, on the scientistic view, is a splitting of Freud's legacy into, on the one hand, a genuinely scientific research program, which is presently underway and making actual progress but has largely left Freud's ideas behind; and, on the other, a loosely formulated psychological wisdom which has humanistic value but lacks strict truth and must submit itself to scientific regulation.

There is a great deal to be said about the general problems which flow from this dissociation of fact from value, and of scientific 
from ordinary understanding of human beings, but a more direct response is available. The charge of substituting confabulations of meaning for empirical reality rests on a confusion, in so far as what is assumed in hermeneutical readings of Freud is simply that interpretation provides the core means by which psychoanalysis traces the contours of mental phenomena - an epistemological claim to which questions of underlying causal ontology are secondary if not irrelevant, and which could not be controverted without impugning the entire apparatus of common sense psychology. It is true of course that, just as some naturalists perceive intentional idioms as inimical to genuine explanation, at least some hermeneutical readers of Freud contest the general metaphysics of scientific realism ("positivism" or "objectivism"). But the fact that psychoanalysis raises so acutely the question of the relation of meaning and causality - and thereby re-occasions the ancient quarrel of scientific realists and hermeneuticists - does not mean that it should be expected to contain the resources for resolving this wholly general philosophical issue. The real question is whether psychoanalytic interpretation, equipped with its basic assumptions concerning the shape of the mind, is arbitrary in ways that ordinary psychological interpretation is not. Critics of hermeneutical readings of Freud have not shown that this is the case.

If we are to give an account of psychoanalysis which conserves its hermeneutical dimension, then two questions need to be addressed. First we must ask to what extent psychoanalysis is committed implicitly, by virtue of the role it accords to interpretation, to the standpoint of philosophical hermeneutics, and if so, whether making this commitment explicit entails revisions to psychoanalytic theory. One possibility, accordingly, is that hermeneutical reflection reveals the need for an overhaul of psychoanalytic theory that purges it of elements which fail to agree with the general conception of psychological life as constituted throughout by practices of understanding and interpretation. We will see that this is the option developed by Habermas. 
The second question is whether, assuming some sort of challenge to be posed, psychoanalysis forces adjustments on hermeneutics. The possibility to be explored here is that psychoanalysis shows its limitations as a general approach to human understanding, or at the very least, the need to draw a distinction within hermeneutics between two different tasks and types of theory or interpretative practice, one pitched at self-consciously articulated meaning and the other at its non-conscious underpinnings. This we will see is roughly the answer returned by Ricœur.

\section{THE PROBLEM FACING A HERMENEUTICAL CONSTRUAL} OF FREUD: SARTRE AND WITTGENSTEIN

To get the task into better focus, we may look at two early critical appraisals of Freud: Sartre's treatment of psychoanalysis in his short essay on the emotions from 1939, and Wittgenstein's remarks on Freud from the 1940s as reported in Lectures and Conversations. Both Sartre and Wittgenstein decline to take at face value Freud's self-affiliation to the natural sciences, and have some sympathy with Freud's project, but proceed to identify, from different angles, one and the same deep conceptual problem for psychoanalytic explanation as construed hermeneutically. ${ }^{11}$

1. Here is what Sartre says on the subject of psychoanalytic symbolism:

The psychoanalytical interpretation considers the phenomenon of consciousness as the symbolic realization of a desire repressed by censorship. Let us note that for consciousness this desire is not implicated in its symbolic realization. Insofar as it exists by and in our consciousness, it is only what it appears to be: emotion, desire for sleep, theft, phobia of bay-trees, etc. If it were otherwise and if we had some consciousness, even implicit, of our real desire, we should be dishonest; the psychoanalyst does not mean it that way. It follows that the signification of our conscious behaviour is entirely external to the behaviour itself, or, if one prefers, the thing 
signified is entirely cut off from the thing signifying. The behaviour of the subject is, in itself, what it is (if we call "in itself" what it is for itself), but it is possible to decipher it by appropriate techniques as a written language is deciphered. In short, the conscious fact is to the thing signified as a thing, the effect of a certain event, is to that event, for example, as the traces of a fire lit on the mountain are to the human beings who lit the fire. Human presences are not contained in the ashes which remain. ${ }^{12}$

Freud, as Sartre understands him, wishes to conceive the conscious phenomena for which he offers psychoanalytic interpretations affects and desires, and the instances of behavior which express them - as essentially unified with their underlying unconscious motivation, in just the way that the ordinary course of mental life presents us with intelligible wholes. But this cannot be done, Sartre argues, because the essential principle of all such unities, namely the subject's taking-X-as-meaning- $Y$, is necessarily missing; if it were present, then we would have make-believe, "dishonesty," or some other non-psychoanalytic mental configuration. The underlying problem, which Sartre expands on in his critique in Being and Nothingness, ${ }^{13}$ is that Freud employs at one and the same time two incongruent models of the human subject, one that affirms its absolute unity and another that distributes its contents over a manifold of psychic parts. The first model affirms a One over the Many, and is in play when Freud asserts that $\mathrm{X}$ means $\mathrm{Y}$; the second affirms a mere Many without a unifying One, and is employed when Freud tries to tell us what X's meaning Y consists in, and why we should accept the attribution. Freud's naturalism, Sartre argues, abets this incoherence.

Sartre does not, however, regard Freud's undertaking as an overall failure. Though he rejects Freud's claim to have provided a theoretical solution, he believes that psychoanalytic conceptualization nonetheless succeeds in bringing to light the paradoxical character of human motivation, and this explanandum furnishes the subject matter for Sartre's own hermeneutical project: his attempt by means 
of "existential psychoanalysis" to understand the individual as an irreducible whole, an entity which is meaningful all the way down. ${ }^{14}$

2. Wittgenstein's remarks are only fragments, and he should not be regarded as engaging in a systematic critique of Freud, but two things that clearly draw his attention in The Interpretation of Dreams (the only Freudian text named) are the question of criteria When should interpretation stop? What gives one interpretation the right to exclude alternatives? - and the more fundamental question of whether the concept of meaning has coherent application to dreams at all. Also in question, therefore, are Freud's notions that dreaming evinces thinking, employs symbols, fulfills wishes, and so on, along with his reapplication of these psychological schemas to symptoms and public behavior.

Observing that Freud's dream symbols fall between nature and convention, Wittgenstein says:

Consider the difficulty that if a symbol in a dream is not understood, it does not seem to be a symbol at all. So why call it one? But suppose I have a dream and accept a certain interpretation of it. Then - when I superimpose the interpretation on the dream - I can say "Oh yes, the table obviously corresponds to the woman, this to that etc." 15

This might be taken, not as a dismissal of psychoanalytic interpretation but as a basis for validating talk of dream-symbolism indirectly, in so far as the meaning of dreams may be regarded as a function of our later reflection on them; Wittgenstein at any rate seems to intimate that this approach could be adopted without incoherence. What however emerges clearly from Wittgenstein's discussion is his view of the speculative and philosophically driven character of Freud's full psychology: dreams do indeed puzzle us and invite interpretation, but what fundamentally underwrites Freud's ideas, Wittgenstein maintains, is a demand for complete explanation, a conviction that mental events are sufficiently determined; only this philosophical prejudice could justify the various auxiliary ideas introduced by 
Freud, in particular the notion of mental force which underpins his conception of wish-fulfillment. ${ }^{16}$

The upshot is, Wittgenstein implies, a compromised style of theorizing: Freud is drawn to the possibility, which nothing in ordinary psychological understanding precludes a priori and which its open-endedness perhaps invites, of making deeper sense of the mind by exploiting, not experimental methods, but the kinds of non-propositional pattern-making that we are familiar with from aesthetic contexts; hence the affinity of dream-interpretation with judgments of correctness in the interpretation of music, painting, and so on. Freud however seeks to convert his interpretative suggestions into doctrines, and, having come so far, is obliged to take further scientistic turns in order to substantiate speculations which have outrun their warrant; at which point he betrays the original impulse which sponsored his reflections. What results is a mere "mythology," albeit a powerful one. ${ }^{17}$

Wittgenstein's reservations rest on a conception of meaning forged in the intersubjective context of natural language, while Sartre's turn on the intra-subjective self-relation, but they concur in finding Freud's hermeneutical conceptualization of the phenomena less than fully intelligible. Both accept that there is an authentic element motivating psychoanalytic reflection, but consider it occluded in Freud's theorizing: what begins as a legitimate attempt to locate a type of meaning to which natural science is necessarily blind, is forced into scientistic directions, and ends in absurdity.

A defender of Freud may seek to meet these objections. The effectiveness of Sartre's argument is limited, not by his Cartesian commitment to the transparency of the mental, which he suspends for the sake of argument, but by his strong assumptions concerning what might be called its architecture: Sartre assumes the full determinacy of mental life and transitivity of mental connections, as if assimilating the mind in toto to a single practical syllogism. ${ }^{18}$ Since this is not an assumption that common sense psychology agrees 
with, Freud can reject Sartre's objection as relying question-beggingly on a rationalistic, or Kantian, idealization of the mental.

The Freudian reply to Wittgenstein is that the general view of meaning which would make it necessary to treat symbolism as the mere outcome of interpretative activity, and not as its independently real object, is unduly restrictive, and overly driven by a concern for empirical anchoring, in a way that gives excessive weight to skeptical worries. To be sure, if psychoanalysis were in the business of setting up psychological attributions $a b$ initio - or of making them criteriologically impregnable in the face of other-minds skepticism - then it can be agreed that it would run afoul of Wittgenstein's conditions. But in fact psychoanalysis takes ordinary psychology's attributions for granted, without either contesting or seeking to revalidate them: its aim is rather to elaborate, deepen, and build on them, ${ }^{19}$ and there is no obvious reason why this "second wave" of interpretation should be bound by the same rules as govern the ground-floor of interpersonal understanding.

These replies reduce the force of the Sartre-Wittgenstein objection, but without altogether meeting their challenge. For what has been said is only that certain strong, philosophically committed views of psychological understanding - Sartre's idealization or Wittgenstein's semi-verificationism - must be rejected in order for psychoanalytic enquiry to be launched. But this is not to say what alternative conception would positively serve Freud's purposes. With this question in mind, we turn to the constructive proposals of Habermas and Ricœur.

THE MAJOR THEORETICAL PROPOSALS: HABERMAS AND RICOEUR

Habermas and Ricœur's main writings on Freud, respectively Knowledge and Human Interests [Erkenntnis und Interesse] and Freud and Philosophy, both landmarks in the philosophy of psychoanalysis, appeared in the 1960s, and arose in different philosophical settings. Habermas belonged to the Frankfurt School and Ricœur's 
associations were with Husserl. Neither critical theory nor phenomenology as such being the present topic, our focus is confined to the significance of their thought for a hermeneutical construal of psychoanalysis. The main contrast lies between Habermas's attempt to resolve the problem by making psychoanalysis an unequivocally hermeneutical discourse, eliminating the ambiguity altogether, and Ricœur's strategy of setting psychoanalysis' dual commitments in a broader philosophical context, which allows what seems a problem peculiar to psychoanalysis to be regarded as the resurgence of a more fundamental philosophical opposition, the resolution of which is not a task which Freud alone can be expected to fulfill.

1. Habermas' discussion is explicitly reconstructive, and aims to sift out what is cogent and philosophically defensible in Freud while discarding what belongs to his "scientistic self-misunderstanding" (on this point concurring with Sartre and Wittgenstein). This does not mean, however, that the metapsychology should be rejected, or paraphrased away, as other, softer hermeneutical readings of Freud recommend. ${ }^{20}$ To the contrary, it is here that Habermas finds the deepest points of contact with his own program of regrounding critical theory. Metapsychology is, Habermas states, "a general interpretation of self-formative processes": ${ }^{21}$

The model of the three mental agencies, id, ego, and super-ego, permits a systematic presentation of the structure of language deformation and behavioural pathology. Metahermeneutic statements can be organized in terms of it. They elucidate the methodological framework in which empirically substantive interpretations of self-formative processes can be developed. ${ }^{22}$

Habermas's reconstruction of psychoanalysis proceeds on the basis that communicative action provides the measure of rationality. It takes as primary the dialogic situation, ${ }^{23}$ artificially reproduced in the therapeutic context, of one person's failure to make sense to another, with the distinguishing feature that here the inability to make oneself 
intelligible to the other corresponds to, and arises from, an avowed failure to make oneself intelligible to oneself. Habermas's key claim is not merely that the intrasubjective disturbance can be modeled on intersubjective breakdown, but that it consists in communicative failure. That is to say, we are to abandon the realist conception of the unconscious as a set of phenomena defined by the difficulty they pose for cognition, and instead regard it as constituted by abortive communicative action. This is developed into the following picture:

The object domain of depth hermeneutics comprises all the places where, owing to internal disturbances, the texts of our everyday language games are interrupted by incomprehensible symbols. These symbols cannot be understood because they do not obey the grammatical rules of ordinary language, norms of action, and culturally learned patterns of expression [...] [S]ymptoms are signs of a specific self-alienation of the subject who has them. The breaks in the text are places where an interpretation has forcibly prevailed that is ego-alien even though it is produced by the self. Because the symbols that interpret suppressed needs are excluded from public communication, the speaking and acting subject's communication with himself is interrupted. The privatized language of unconscious motives is rendered inaccessible to the ego. ${ }^{24}$

Habermas suggests that even psychoanalysis' aspiration to general laws - the feature which does most to make its discourse look like scientific causal hypothesizing - can be salvaged: these offer "a narrative background" or "dramatic model" with reference to which "interrupted self-formative processes can be filled out and become a complete history." 25

The dynamic unconscious has, according to Habermas, not had to produce meanings ex nihilo, as Sartre and Wittgenstein assume, rather it has deformed meanings previously in circulation. Thus Habermas may agree with Sartre that Freud's mental partition fails to 
elucidate the incoherence within the subject, while asserting that its correct explanation lies in distorted self-communication, and answer Wittgenstein by granting that the usual conditions for meaning are not met, and then maintaining that this is not because language is absent but because its condition is defective. It follows from Habermas's account that what may seem to be sheer force operative in psychic life is such only in appearance; in reality it consists in a failure, or refusal, to articulate meaning. ${ }^{26}$ Habermas may accordingly be described as defending a privative conception of the unconscious. ${ }^{27}$ These are the essential points on which Ricœur differs from Habermas.

2. Salient in Ricœur's account of Freud are (1) his characterization of psychoanalysis, alongside Marx and Nietzsche, as engaged in a "hermeneutics of suspicion," 28 (2) his claim that psychoanalysis has immediate philosophical import, and (3) his attribution of a nonhermeneutical "realism" to Freud.

The first of these, though well known, is problematic. The hermeneutics of suspicion designates not a special technique of interpretation but a special goal of hermeneutical enquiry, namely, of deciphering and unmasking. This assumes that the discourse under examination does not mean what it says, or means more than it says. How does this "prejudice" or pre-judgment, of disbelief or refusal to take at face value, arise? It cannot be prompted by anything at the surface of the discourse, since this is held to be self-concealing. It seems that some pre-hermeneutical hypothesis must be already in situ. In the case of Marx and Nietzsche, the relevant suspicion-grounding hypotheses are perhaps not hard to locate, but psychoanalysis is not premised on the falsity of the mental as ordinarily conceived: what motivates it is the failure of common sense psychology to make sense of some of what it is presented with, not the presumed falsity of common sense psychology, and this generates a need for explanation, not a ground for suspicion. To this extent Gadamer's objection that Ricœur fails to differentiate a distinctive sub-species of hermeneutics appears justified. ${ }^{29}$ 
The better point of entry to Ricœur is his claim that Freud's ideas have direct impact on two high-level, inter-connected assumptions of modern philosophy: that consciousness and self-consciousness are irreducible, and that individual human subjects possess a deep autonomy which also occupies a privileged position in philosophical reflection. Situating psychoanalysis at the same level as Descartes and Kant, Ricœur declares:

The reading of Freud is also the crisis of the philosophy of the subject. It imposes the dispossession of the subject such as it appears primarily to itself in the form of consciousness. It makes consciousness not a given but a task. The genuine cogito must be gained through the false cogitos that mask it [...] And so I say that Freud can be read just as our colleagues and teachers read Plato, Descartes, and Kant. ${ }^{30}$

What does this "dispossession" consist in? The answer lies in what Ricœur calls Freud's realism, by which he means that, in characterizing the unconscious economically and topographically, Freud accords the mental the same degree of reality as external physical objects, and of a partially analogous kind. At a minimum this means that at least some of the entities which compose the mind are experienced unconsciously in a quasi-objectual manner: they exist for the subject as having the features which Freud's economic-topographical descriptions pick out. ${ }^{31}$ The image of the unconscious as composed of a kind of affective stuff, which Habermas eliminates, is to that extent restored: mental opacity is unlike the obscurity which texts present, for the mind is pictured as set over against itself in a way which contrasts with mere cognitive deprivation. On this basis Ricœur can assert that consciousness, having discovered that "its immediate self-certainty was mere presumption," "must be lost in order that the subject may be found." 32

Ricœur does not grant Freud a one-sided victory over traditional philosophy, as a naturalist might. Rather his claim is that the 
antinomy of the objective reality of the mental versus self-conscious subjectivity manifests itself within psychoanalysis: this is what its mixed discourse commits it to. As regards the further question of what, granting the antinomy, is to be done about it, Ricour's answer is that it has no purely theoretical solution and remains a task for the practice of reflection, which is guided by the "limit-idea" of its overcoming. ${ }^{33}$

Ricœur's proposal may be understood in the following terms. Discussion of psychoanalysis, including that of Habermas, proceeds on the assumption that it presents us with a problem that demands a theoretical solution. Ricœur's radical alternative is to suppose that what appears to reflection as its own conceptual problem, in fact represents a real opposition within its object - meaning not simply that the phenomena exhibit different kinds of first-order properties, some meaning-constituted and others not, but that this very heterogeneity reflects a more basic underlying schism in our constitution. The "enigma of Freudian discourse" then becomes, as Ricœur puts it, a constitutive "paradox of reflection," grounded in the nature of its object, human existence. ${ }^{34}$

In order for this to qualify as a positive solution, more must of course be said to recommend it, both as a reading of Freud and as a general philosophical strategy, and here two things can be said quickly. One is that Ricœur's solution will appeal to anyone who, like Ricœur himself, is impressed by the claim of classical German philosophy that human reality stands under an overarching opposition of Freedom and Nature, or spirit and nature - a notion which goes against the grain of philosophical hermeneutics, which has largely followed Herder in regarding Kant's dualism as a mistake. The other is that plausibly the antinomy is attested a posteriori. Integral to the ambiguous character of psychoanalysis' primary explananda is an internal dissonance: the reflexive perplexity of the Ratman or Wolfman involves a positive apprehension of inner incoherence, which goes beyond mere failure of rational competence. 


\section{FREUD'S REALISM: THE "MENTAL APPARATUS"}

\section{AS A CONTAINER OF MEANING}

Habermas and Ricœur are guided to a considerable extent in their treatments of Freud by broader agendas - Habermas is seeking to reconstruct critical theory, and Ricœur to measure the claim of phenomenology to comprehensive philosophical truth - and they introduce concepts which do not belong to Freud's own conceptual repertoire. Let us now go back to Freud and try to determine, in terms closer to his own, what philosophical factors drive his theory construction. The story of Freud's own development is a large and well-trodden area, ${ }^{35}$ and I will confine myself here to a specific angle, which helps us to locate the difficulty in marrying psychoanalysis to hermeneutics.

1. Broadly speaking, behind Freud's innovations lie two great nineteenth-century legacies: the tradition of classical German philosophy, and that of empirical psychology, which provide respectively the bare concept of the dynamic unconscious, and the notion /widely if not universally accepted in late nineteenth-century psychological theory) that particular attributions of unconscious mental states can be warranted on strictly empirical grounds. ${ }^{36}$ In "The Unconscious" and his other key metapsychological papers of 1915, as in almost all Freud's writings, only the intellectual authority of the latter tradition is acknowledged, although the legacy of the former is presupposed. Also in the foreground is Freud's confidence that the metaphysical integrity of the mental is attested in conscious experience: conscious mentality as such does not, Freud implies, pose any puzzle. On this basis Freud is able to present the possibility of psychoanalytic Wissenschaft as turning on a single, essentially simple consideration:

Our right to assume the existence of something mental that is unconscious and to employ that assumption for the purposes of scientific work is disputed in many quarters. To this we can reply that our assumption of the unconscious is necessary and legitimate, and that we possess numerous proofs of its existence. 
It is necessary because the data of consciousness have a very large number of gaps in them. ${ }^{37}$

Once the conceptual possibility of unconscious mental states has been granted, the way to psychoanalysis is clear, Freud argues, for the manifest existence of "gaps" in conscious mental life provides sufficient reason for positing causes outside it. That these causes must be mental rather than physical follows from the fact that they are adduced to explain lacunae in consciousness, which means restoring its continuity, something which descriptions of brain and other physiological states cannot do. But since ex hypothesi the contents of consciousness are unable to supply the missing links, or indeed to account for the original existence of the gaps, we are entitled to infer that the interpolated causes have a specific nature and type of causality of their own - in other words, that the mental has varieties, of which its familiar conscious instances are only one. ${ }^{38}$

Freud thus takes himself to have arrived, by a relatively direct, quasi-conceptual route at the theoretical picture which emerges from his interpretative studies of mental phenomena. Freud believes his argument conforms with accepted, abductive modes of scientific reasoning, which is plausible, and in addition he is confident of having shown the concept of unconscious mentality to be unproblematic, despite the intense dispute which had earlier surrounded it. The only philosopher who exerted direct personal influence on Freud (and commanded his admiration), Franz Brentano, had in fact explicitly rejected the concept as both unnecessary and incoherent. Understanding Freud as replying to Brentano, I will try to show, gives reason for thinking that Ricœur's account of Freud is essentially correct.

The parameters of Freud's 1915 argument become more distinct if we consider it in the light of Brentano's Psychology from an Empirical Standpoint, first published in 1874. Brentano's aim in this influential work, which does not belong to the hermeneutical tradition but shares some of its philosophical motivation, ${ }^{39}$ was to 
establish psychology on an autonomous footing and to elevate its scientific standing: the proper position of psychology in the order of justification of human knowledge, Brentano asserts, is foundational (a claim which no doubt appealed to Freud). ${ }^{40}$ This involves gaining at the outset an accurate understanding of what fundamentally distinguishes mental from physical phenomena. Brentano's answer to this question is often said to be the possession of intentionality a mental phenomenon is one that has "content" or "reference to something as an object" - but this is strictly inaccurate, for Brentano defines a mental phenomenon as one which not only possesses intentionality but in addition has real or actual, as opposed to merely phenomenal, existence. ${ }^{41}$

Brentano grounds this realism concerning the mental on the epistemological fact that we enjoy certainty regarding our mental states. This allows him to claim for psychology exactly the same legitimating ground as other sciences - namely, data or "presentations" in consciousness - but, if Brentano is right, without obliging it to follow their model of theorizing. Whereas all other sciences rest on theoretical inferences from what is given in experience - the data of outer consciousness, which have merely phenomenal existence to their unobservable causes, psychology arrives at an explanatorily final reality through mere description of what is perceived, in inner consciousness. Consistently with this position, Brentano launches an extended attack on the hypothesis of unconscious mental phenomena, talk of which, he argues, may be reduced without remainder to that of mere dispositions to conscious states..$^{42}$

Now, when Freud asserts the existence of unconscious mental states, he is clear that they are to be understood in unqualifiedly realistic terms, and the point is of course crucial, since a dispositional analysis along the lines recommended by Brentano would stymie psychoanalytic theorizing at the outset, by making it impossible to postulate a source of mental agency independent of the conscious subject. Freud accordingly deserts Brentano's thesis of the explanatory finality of the mental qua conscious, and maintains instead that 
our epistemic relations to inner-mental and outer-physical reality are symmetrical: ${ }^{43}$ contra Brentano, who had argued that, if the principles of reasoning which take us from sense impressions to the entities and forces of chemistry and physics are duplicated internally, then we are led, if anywhere, to something not merely unconscious but also non-mental. If inner perception were inner observation, Brentano argues, then the phenomena observed would fail to qualify as mental rather than physical ${ }_{i}^{44}$ symmetry of inner and outer perception would reduce mental phenomena, like physical phenomena, to mere "signs" of a reality which causes them..$^{45}$ Brentano's point here recalls Sartre's objection to Freud: the allegation is again that slackening the relation of the mental to conscious presentation results in absurdity.

Freud's reply, the hermeneutical dimension of his thought here coming to the fore, is that Brentano has a false or at any rate incomplete picture of what it is for there to be data or "presentations" in consciousness. It is not that there is no quasi-perceptual aspect to conscious mental states, but that when such acquaintance is present, it necessarily involves understanding. Ordinary instances of emotion show this: a feeling of joy or sorrow involves taking the mental episode in question as having that particular determinate meaning. If this is correct, then it is possible to see how, when we extrapolate interpretatively from the data of consciousness to the unconscious, we are not deserting the field of psychology: what may legitimately be supposed is that different species of mentality exhibit different ratios of interpretable content and perceptual presence, and that the mental states which comprise the contents of Ucs. lie at one end of the spectrum; they construe the self and its world in ways which preclude the possibility of their direct manifestation or reflective retrieval. Certainly these unconscious construals present the subject with objects - of a more or less phantastical kind - but they do so without themselves being the object of any higher-level presentation, and hence without any accompanying judgment. ${ }^{46}$ These complex features are not possessed by all species of the mental, and if Brentano builds them into his analysis, then it is because he confuses 
the reality of the mental in general with the certainty of its conscious instances. A correct psychological realism, in Freud's view, leads by default to the unconscious.

2. To this extent Freud's realism and his hermeneuticism are in one another's service. To now bring into view the other side of Ricœur's picture - the respect in which Freud's realism departs from the hermeneutical standpoint - we may turn to a later paper, in which Freud resumes his implicit dialogue with Brentano.

In "Negation" (1925) Freud offers an account of the logical function of negation. In the following passages we see the characteristic pattern of Freud's reasoning, in which the motive of interpretation - to achieve a better understanding of what is given - combines with speculative ambition:

The manner in which our patients bring forward their associations during the work of analysis gives us an opportunity for making some interesting observations. "Now you'll think I mean to say something insulting, but really I've no such intention." We realize that this is a repudiation, by projection, of an idea that has just come up [...]

Thus the content of a repressed image or idea can make its way into consciousness, on condition that it is negated. Negation is a way of taking cognizance of what is repressed; indeed it is already a lifting of the repression, though not, of course, an acceptance of what is repressed [...]

Since to affirm or negate the content of thoughts is the task of the function of intellectual judgement, what we have just been saying has led us to the psychological origin of that function. To negate something in a judgement is, at bottom, to say: "This is something which I should prefer to repress." A negative judgement is the intellectual substitute for repression; its "no" is the hall-mark of repression, a certificate of origin - like, let us say, "Made in Germany." With the help of the symbol of negation, thinking frees itself from the restrictions of repression 
and enriches itself with material that is indispensable for its proper functioning $[\ldots]$

The study of judgement affords us, perhaps for the first time, an insight into the origin of an intellectual function from the interplay of the primary drive impulses [Triebregungen]. Judging is a continuation, along lines of expediency, of the original process by which the ego took things into itself or expelled them from itself, according to the pleasure principle. The polarity of judgement appears to correspond to the opposition of the two groups of drives [Triebgruppen] which we have supposed to exist. Affirmation - as a substitute for uniting - belongs to Eros; negation - the successor to expulsion - belongs to the drive towards destruction [Destruktionstrieb]. ${ }^{47}$

A recurring clinical datum - the phenomenon of sincere but selfignorant disavowal: "I've really no such intention" - is brought under an interpretation - the repressed is able to figure in consciousness on the condition of its negation - prompting a complex hypothesis which again initially follows Brentano and then departs from him. Freud agrees with Brentano that judgmental affirmation and negation are acts of acceptance and rejection, continuous with the emotions of love and hate. But he then hypothesizes, contradicting Brentano, that (1) both judgmental and conative-affective negation (and affirmation) are a single type of mental act, ${ }^{48}(2)$ the judgmental form of negation is derivative from and dependent on its primary conativeaffective form, and (3) both forms have a single source, which may be conceptualized in two different ways, either at the level of (phantasies of) bodily processes or at that of drives.

Freud's hypothesis concerning judgment überhaupt recommends itself by virtue of the way in which it deepens the original interpretation concerning the role of negation in facilitating a return of the repressed, while also cohering with other parts of psychoanalytic theory. What makes the speculative extrapolation in "Negation" particularly interesting for present purposes is that it shows Freud 
seeking to, as it were, get behind the back of meaning. Freud's aim is to grasp the source of judgment, not for the sake of hermeneutical completeness - he does not suggest that the logical function of negation itself sets any problem of understanding, for which his account might provide a (psychologistic) solution - but in order to achieve a fundamental insight into the "proper functioning" of conscious intellectual life, which we do by forming a unitary concept of what grounds and contains meaning. Freud's ultimate theoretical concern, led by his realism, is therefore with, as I put it earlier, the "shape" of the mental apparatus. In grasping it, we break out of the hermeneutical circle, or at any rate reach its outermost sphere, the unmoving prime mover of the mental. ${ }^{49}$ And we can see how this promises to solve the Sartre-Wittgenstein problem: if Freud's conjectures concerning the underlying shape of the psyche allow us to conceptualize a new way in which a subject may mean something, then Freud's claims are not properly measured by any antecedently formed conception of what this consists in. Put differently, the particular kind of "depth" interpretation offered by Freud does not amount only to an extension of hermeneutical range, rather his foundational claim is that the mind has depths in a sense not previously recognized.

Now it may be objected that even at the end of the day Freud remains within meaning, in so far as his life and death drives have "aims" (Triebziele), and the corporeal processes and phantasies which express them have a rudimentary teleological organization. This raises a difficult, broad question concerning the demarcation of meaning from whatever is held to stand in contrast with it, concerning which different hermeneutical thinkers take different positions. But it is worth noting that at this point we are presented with a further possibility, intimated (but not developed) by Ricœur. ${ }^{50}$ If drives and embodiment do not merely ground and contain meaning, but are themselves imbued with it, then meaning bleeds all the way down into nature, just as late eighteenth- and early nineteenth-century Naturphilosophie had proposed. In Sections V-VI of Beyond the Pleasure Principle (1920), Freud shows his willingness to entertain 
and defend the unmistakeably naturphilosophisch notion that our drives inhere in organic life as such (and indeed originate in its very differentiation from the inorganic). ${ }^{51}$ In so doing he distances himself from hermeneutical orthodoxy. But Freud may also be regarded as returning to an early point in the history of hermeneutics, later abandoned. Friedrich Ast, writing in 1808 under the influence of Schelling, asserts the unity of the modern hermeneutical project with the philosophy of nature: no understanding and interpretation of alterity is possible, Ast declares, "without the unity and identity of all that is spiritual and the original unity of all things in spirit." ${ }^{\prime \prime 2}$ In speculative moments, Freud agrees with Ast that, in order to make sense of human beings, we must offer an interpretation of nature as a whole.

\section{NOTES}

1 Freud's famous phrase, applied to dream-interpretation, in The Interpretation of Dreams, in the Standard Edition of Freud's works (London: Hogarth Press and Institute of Psycho-Analysis, 1953), ed. James Strachey, 24 vols., vol. V, 608. References to this edition, giving volume and page number, are henceforth prefixed SE.

2 SE IV:100-2.

3 See John Forrester's detailed account of the ways in which linguistic themes inform Freud's development, Language and the Origins of Psychoanalysis (New York: Columbia University Press, 1980).

4 "The Unconscious" (1915), Pts. II-IV, SE XIV:172-85.

5 "The Unconscious" (1915), Pt. V, SE XIV:186-9.

6 See SE V:339-40.

7 Concerning the relation of "word-presentations" to consciousness, see SE XIV:200-3. Freud's account falls short of any full philosophical thesis concerning the linguistic nature of thought.

8 See Adolf Grünbaum, The Foundations of Psychoanalysis: A Philosophical Critique (Berkeley: University of California Press, 1984), and Patricia Kitcher, Freud's Dream: A Complete Interdisciplinary Science of Mind (Cambridge, MA: MIT Press, 1993).

9 SE V:536 and XIV:168. 
10 See Grünbaum, The Foundations of Psychoanalysis, Introduction, "Critique of the Hermeneutical Conception of Psychoanalytic Theory and Therapy."

11 Heidegger criticizes Freud in terms that overlap with Sartre's and Wittgenstein's: see his Zollikon Seminars from 1964 and 1966, ed. Medard Boss, trans. Franz Mayr and Richard Askay (Evanston: Northwestern University Press, 2001), esp. 20-4, 113-21, and $168-70$.

12 Jean-Paul Sartre, The Emotions: Outline of a Theory (1939), trans. Bernard Frechtman (London: Routledge, 2002), 44-5.

13 Jean-Paul Sartre, Being and Nothingness: An Essay on Phenomenological Ontology (1943), trans. Hazel Barnes (London: Routledge, 1995), 50-4.

14 Sartre, Being and Nothingness, 560-75. Sartre practices existential psychoanalysis in his biographies of Baudelaire, Genet, and Flaubert. Heidegger's hermeneutic of Dasein is transposed into psychoanalysis by Ludwig Binswanger and Medard Boss. Sartre's commitment to the hermeneutical standpoint is more limited than Heidegger's: Sartre grants no privileged role to language (Being and Nothingness, 3724), subordinates being-for-others to the structures which define the pour-soi, and regards intersubjective meaning as a contradictory phenomenon.

15 Ludwig Wittgenstein, Lectures and Conversations on Aesthetics, Psychology, and Religious Belief, ed. Cyril Barrett (Oxford: Blackwell, 1966), 44.

16 Wittgenstein, Lectures and Conversations, 42-4, 49-50.

17 Wittgenstein, Lectures and Conversations, 52.

18 Sartre affirms this implication in Being and Nothingness, 464, 55764: there is an "original choice of self."

19 Analytic philosophy has pursued this idea by conceiving of psychoanalysis as an extension of common sense psychology: see Richard Wollheim, Freud, 2nd edn. (London: Fontana, 2008), Supplementary Preface.

20 E.g., Roy Schafer, "Narration in the Psychoanalytic Dialogue," Critical Inquiry 7:1 (1980): 29-53.

21 Jürgen Habermas, Knowledge and Human Interests (Erkenntnis und Interesse, 1968), trans. Jeremy Shapiro (Boston: Beacon, 1971), 254. 
22 Habermas, Knowledge and Human Interests, 258.

23 Habermas, Knowledge and Human Interests, 252.

24 Habermas, Knowledge and Human Interests, 226-7; see also 256-7, where Habermas records his indebtedness to Alfred Lorenzer, whose hermeneutical theory is stated comprehensively in Die Wahrheit der psychoanalytischen Erkenntnis. Ein historisch-materialistischer Entwurf (Suhrkamp: Frankfurt am Main, 1974). Lorenzer incorporates especially with his Kleinian concept of "scenic understanding" (11015) - elements not taken up by Habermas.

25 Habermas, Knowledge and Human Interests, 259-60. It is notable that Habermas - in contrast with other critical theorists, whose readings of Freud are not similarly austere and who characteristically approve Freud's drive theory - does not look to psychoanalysis for substantive explanation of the social world: its chief role is to provide a validating model for ideology-critical reflection. Habermas's remarks in Theory of Communicative Action, vol. 2, Lifeworld and System (1980), trans. Thomas McCarthy (Boston: Beacon, 1987), 99-100, show Freud to have been displaced by Mead.

26 Habermas's account of the relation of causality to meaning in psychoanalysis is complex: see Knowledge and Human Interests, 2567, 271-2, and Grünbaum's corresponding criticisms in The Foundations of Psychoanalysis, 9-15. On the question of what inner nature amounts to for Habermas, see his comments in reply to Thomas McCarthy, in John B. Thompson and David Held, eds., Habermas: Critical Debates (Cambridge, MA: MIT Press, 1982), 342-5.

27 Habermas, Knowledge and Human Interests, 241-2: the act of repression is reduced to "a banishment of need interpretations," a "splitting-off of individual symbols from public communication." A profound challenge to Habermas's assumption that linguistic communication is where we are most truly at home is posed by Lacan, who agrees that language is the key to the unconscious, but claims that we are necessarily alienated in and by it: in acceding to the "Symbolic" order and uniting herself communicatively with others, the subject divides herself. Language is therefore the source of the intra-subjective disturbance posited by Habermas.

28 See Paul Ricœur, Freud and Philosophy: An Essay on Interpretation (De l'interprétation. Essai sur Freud, 1965), trans. Denis

Savage (New Haven: Yale University Press, 1970), 25-7, 33-5, 
53-5, 59-64. Also important are the essays in The Conflict of Interpretations: Essays in Hermeneutics, trans. Willis Domingo (Evanston: Northwestern University Press, 1974), Pt. II, and On Psychoanalysis (Cambridge: Polity, 2012). Ricœur criticizes Habermas's theory in "The Question of Proof in Freud's Writings" (1977), in On Psychoanalysis, 11-49.

29 Hans-Georg Gadamer, "The Hermeneutics of Suspicion," in Hermeneutics: Questions and Prospects, ed. Gary Shapiro and Alan Sica (Amherst: University of Massachusetts Press, 1984): every form of hermeneutics is "a form of overcoming of an awareness of suspicion," in so far as we must always look for "the real meaning of an utterance" $(54,63)$.

30 Ricœur, The Conflict of Interpretations, 161-2.

31 Ricœur, Freud and Philosophy, Bk. II, Pt. I. Cf. Richard Wollheim, "The Mind and the Mind's Image of Itself," in On Art and the Mind: Essays and Lectures (Cambridge, MA: Harvard University Press, 1974), 31-53.

32 Ricœur, The Conflict of Interpretations, 103, 172.

33 See Ricœur, Freud and Philosophy, 60, 65-7, and "The Unity of the Voluntary and the Involuntary as a Limit-Idea" (1951), in Philosophical Anthropology, trans. David Pellauer (Cambridge: Polity, 2015), 53-71.

34 Ricœur, The Conflict of Interpretations, 173.

35 See Joel Whitebook, Freud: An Intellectual Biography (Cambridge: Cambridge University Press, 2017).

36 See my "The Unconscious: Transcendental Origins, Idealist Metaphysics and Psychoanalytic Metapsychology," in The Impact of Idealism: The Legacy of Post-Kantian German Thought, vol. I, Philosophy and Natural Sciences, ed. Karl Ameriks (Cambridge: Cambridge University Press, 2013), 134-65. Herder, romantic hermeneutics, and Geisteswissenschaften theory are not prominent influences on Freud.

37 SE XIV:166.

38 E.g., SE XVIII:24: consciousness is "not the most universal attribute of mental processes, but only a particular function of them."

39 See Joseph Margolis, "Reflections on Intentionality," in The Cambridge Companion to Brentano, ed. Dale Jacquette (Cambridge: Cambridge University Press, 2004), 131-48. Concerning Brentano's view of hermeneutical issues, see Klaus Hedwig, "Brentano's Hermeneutics," Topoi 6 (1987): 3-10. 
40 Franz Brentano, Psychology from an Empirical Standpoint (1874), trans. Antos Rancurello, D. B. Terrell, and Linda McAlister, ed. Oskar Kraus and Linda McAlister (London: Routledge, 1973), Bk. I, Ch. 1.

41 Brentano, Psychology, 92 and 98: "Knowledge, joy and desire really exist. Color, sound and warmth have only a phenomenal and intentional existence"; mental phenomena alone "possess actual existence [wirkliche Existenz] in addition to intentional existence."

42 Brentano, Psychology, Bk. II, Ch. 2.

43 SE XIV:171: "In psycho-analysis there is no choice for us but to assert that mental processes are themselves unconscious, and to liken the perception of them by means of consciousness to the perception of the external world by means of the sense organs." See also SE V:615-16.

44 Brentano, Psychology, 128.

45 Brentano, Psychology, 19.

46 Brentano, Psychology, 141-2, 153-4, 198-9.

47 "Negation" (1925), SE XIX:235-9 (translation modified). A similar idea figures in Wittgenstein's Philosophical Grammar, ed. Rush Rhees, trans. Anthony Kenny (Oxford: Blackwell, 1974), 58: "|Compare William James on the feelings that correspond to words like 'not,' 'but' and so on.) / ('Not' makes a gesture of rejection. / No, it is a gesture of rejection. To grasp negation is to understand a gesture of rejection.)"

48 Brentano rejects this move in his 1911 Supplementary Remarks, Psychology, 288.

49 The notion of mind as a container becomes extremely important in the post-Freudian theory of Melanie Klein and Wilfred Bion.

50 Noted but not endorsed by Ricœur: Freud and Philosophy, 312-13.

51 SE XVIII:36-9.

52 Friedrich Ast, Grundlinien der Grammatik, Hermeneutik und Kritik (Landshut: Jos. Thomann, 1808), §70, 167-8. See also Ast's proposal for a naturphilosophisch grounding of language, $\S \S 3-5$. 